\title{
DNMT1-mediated PPARa methylation aggravates damage of retinal tissues in diabetic retinopathy mice
}

\author{
Ying Zhu' ${ }^{1}$ Xinru Wang ${ }^{1}$, Xiaoyun Zhou², Lexi Ding ${ }^{1}$, Dan Liu' and Huizhuo Xu*
}

\begin{abstract}
Background: Peroxisome proliferator-activated receptor alpha (PPARa) is associated with diabetic retinopathy (DR), and the underlying mechanism is still unclear. Aim of this work was to investigate the mechanism of PPARa in DR.

Methods: Human retinal capillary pericytes (HRCPs) were treated with high glucose (HG) to induce DR cell model. DR mouse model was established by streptozotocin injection, and then received 5-Aza-2-deoxycytidine (DAC; DNA methyltransferase inhibitor) treatment. Hematoxylin-eosin staining was performed to assess retinal tissue damage. PPARa methylation was examined by Methylation-Specific PCR. Flow cytometry and DCFH-DA fluorescent probe was used to estimate apoptosis and reactive oxygen species (ROS). The interaction between DNA methyltransferase-1 (DNMT1) and PPARa promoter was examined by Chromatin Immunoprecipitation. Quantitative real-time PCR and western blot were performed to assess gene and protein expression.
\end{abstract}

Results: HG treatment enhanced the methylation levels of PPARa, and repressed PPARa expression in HRCPs. The levels of apoptotic cells and ROS were significantly increased in HRCPs in the presence of HG. Moreover, DNMT1 was highly expressed in HG-treated HRCPs, and DNMT1 interacted with PPARa promoter. PPARa overexpression suppressed apoptosis and ROS levels of HRCPs, which was rescued by DNMT1 up-regulation. In DR mice, DAC treatment inhibited PPARa methylation and reduced damage of retinal tissues.

Conclusion: DNMT1-mediated PPARa methylation promotes apoptosis and ROS levels of HRCPs and aggravates damage of retinal tissues in DR mice. Thus, this study may highlight novel insights into DR pathogenesis.

Keywords: DNMT1, PPARa, DNA methylation, Apoptosis, Diabetic retinopathy

\section{Background}

Diabetic retinopathy (DR) is one of the major causes of blindness, and the most common retinal vascular disease [1]. In recent years, the incidence of diabetes and DR has increased year by year, which is a serious threat to human health [2]. In China, the prevalence of DR in diabetic patients is $20-40 \%$ [3]. By 2040, there will be nearly 600 million people with diabetes in the world, and one-third

*Correspondence: xuhzhuo@163.com

${ }^{1}$ Eye Center of Xiangya Hospital, Central South University, No. 87 Xiangya Road, Hunan 410008 Changsha, China

Full list of author information is available at the end of the article of the population will have the performance of DR $[4,5]$. The changes in blood composition of diabetic patients cause dysfunction of vascular endothelial cells, which damages the blood-retinal barrier [6]. The blood-retinal barrier is a restrictive permeable structure that exists between the blood and the retina, and it plays a vital role in ensuring the stability of the retina environment and normal visual function [7]. Increased retinal vascular permeability caused by blood-retinal barrier damage is an important pathological feature in the early stage of DR [8]. In clinical, the onset of DR is relatively insidious, and there is generally no eye symptom in the early stage. Thus, a good time for DR treatment is delayed. original author(s) and the source, provide a link to the Creative Commons licence, and indicate if changes were made. The images or other third party material in this article are included in the article's Creative Commons licence, unless indicated otherwise in a credit line to the material. If material is not included in the article's Creative Commons licence and your intended use is not permitted by statutory regulation or exceeds the permitted use, you will need to obtain permission directly from the copyright holder. To view a copy of this licence, visit http://creativecommons.org/licenses/by/4.0/. The Creative Commons Public Domain Dedication waiver (http://creativeco mmons.org/publicdomain/zero/1.0/) applies to the data made available in this article, unless otherwise stated in a credit line to the data. 
At present, the pathogenesis and treatment of DR have always been the difficulties and hot spots in ophthalmology clinical and basic research [9].

The blood glucose levels of diabetic patients have a great influence on diabetic complications. Random clinical trials have shown that intensive control of blood glucose by injecting insulin to ensure that blood glucose levels are in the non-diabetic range (3.9-6.1 mM), which effectively reduces the incidence of myocardial infarctions, stroke, and cardiovascular disease death $[10,11]$. However, if a diabetic patient with hyperglycemia for a long time, even if the levels of blood glucose are controlled in the later stage, diabetes-related complications are still prone to occur. This phenomenon is called "metabolic memory" [12-14]. The existence of "metabolic memory" has become a major obstacle to diabetic complication treatment, but its mechanism has not been fully elucidated. Many scholars have found that "metabolic memory" is associated with epigenetics [15-17]. Epigenetics reflects the heritable changes in gene expression caused by non-DNA sequence changes, and it embodies the two important concepts of "environment" and "genetic". Miao et al. have clarified the correlation between HbA1c and H3K9ac modifications in the peripheral blood lymphocytes and monocytes of type 1 diabetes mellitus patients [12]. High glucose induces persistent hypomethylation of TXNIP in THP1 cells [18]. Thus, epigenetics is expected to become an important breakthrough in revealing the phenomenon of "metabolic memory", thereby providing new insights for diabetes complication treatment.

As the main content of epigenetics, DNA methylation modification participates in many pathophysiological processes such as embryonic development, stem cell differentiation, genome imprinting, tumorigenesis, inflammation and aging [19]. DNA methyltransferase-1 (DNMT1) is a key enzyme to maintain DNA methylation [20]. DNMT1-mediated MEG3 methylation takes part in the progression of DR [21]. Mishra and Kowluru have found that the global DNA methylation levels are relatively higher in patients with DR [22]. Peroxisome proliferator-activated receptors (PPARs) are a group of transcription factors that belong to the nuclear hormone receptor family. The genes regulated by PPARs are involved in lipid metabolism and insulin resistance [23]. PPAR $\alpha$ participates in the regulation of oxidative stress, inflammation and vascular function [24-26]. Previously, our data has confirmed that fenofibrate inhibits apoptosis of human retinal capillary pericytes (HRCPs) in the early stage of DR by activating PPAR $\alpha$ [27]. In addition, PPAR $\alpha$ is significantly down-regulated in the retina of diabetic patients and high glucose (HG)-treated HRCPs. PPAR $\alpha$ inhibition aggravates microangiopathy and inflammation in streptozotocin (STZ)-induced DR mouse model [28]. Moreover, dietary protein restriction of pregnant rats reduces the DNA methylation levels of PPAR $\alpha$ in hepatocytes of offspring [29]. However, a high-fat diet increases the DNA methylation levels of PPAR $\alpha$ in mice and oocytes of their offspring [30]. Thus, PPAR $\alpha$ methylation may participate in the development of DR. The purpose of this article is to investigate the biological role of PPAR $\alpha$ methylation in regulating apoptosis of HG-induced HRCPs. We further verified that whether inhibition of DNA methylation of PPAR $\alpha$ can reduce damage of retinal tissues in DR mice.

\section{Materials and methods \\ Animals}

C57BL/6 J male mice with 6-8 weeks old (weighting 20-24 g) were purchased from Beijing Vital River Laboratory Animal Technology Co., Ltd. (China). C57BL/6 J mice were housed under specified pathogen free conditions. Animal experiments were conducted in accordance with the Association for Research in Vision and Ophthalmology Statement for the Use of Animals in Ophthalmic and Vision Research, and authorized by the Ethics Committee of Xiangya Hospital, Central South University (No. 201904609; Changsha, China).

C57BL/6 J male mice were divided to three groups $(\mathrm{n}=8)$ : (1) Control group: normal mice were served as control; (2) DR group: DR mouse model was induced by intraperitoneal injection of STZ (50 mg/kg). After $72 \mathrm{~h}$ of intraperitoneal injection, the glucose level of tail vein blood in the mice was examined using automated AccuChek glucometer (Roche Diagnostics, Basel, Switzerland) every 2 weeks. The glucose level of mice more than $250 \mathrm{mg} / \mathrm{dL}$ was deemed as DR mice, and the DR mice were raised for 10 weeks; and (3) DAC group: the DR mice were intraperitoneally injected with 5-Aza-2-deoxycytidine (DAC; $1 \mathrm{mg} / \mathrm{kg} \cdot \mathrm{d}$ ) every day for the last 4 weeks.

After modeling, the mice were euthanized by cervical dislocation. The retinal tissues of mice were rapidly excised and snap-frozen in the liquid nitrogen. The retinal tissues were stored at $-80^{\circ} \mathrm{C}$ for further use.

\section{Cell culture}

HRCPs (Cambrex Biosciences, Walkersville, MD, USA) were cultured in DMEM (Solarbio, Beijing, China) at $37^{\circ} \mathrm{C}$ and $5 \% \mathrm{CO}_{2}$. DMEM contained $10 \%$ fetal bovine serum (FBS) and 1\% penicillin/streptomycin (Solarbio). HRCPs were incubated with $5 \mathrm{mM}$ glucose (normal glucose, NG), $30 \mathrm{mM}$ glucose (HG) or $5 \mathrm{mM}$ 
glucose $+25 \mathrm{mM}$ mannose (Man) with or without $10 \mathrm{mM}$ DAC for $4 \mathrm{~d}$.

\section{The methylation levels of PPARa}

The methylation levels of PPAR $\alpha$ in HRCPs were detected by performing Methylation-Specific PCR (MSP). The genome DNA was extracted from HRCPs using Universal Genomic DNA Extraction Kit (Solarbio). The methylation levels of DNA samples were examined using CpGenome Universal DNA Modification (Merck Millipore, Billerica, MA, USA) following the instruction of manufacturer. The primers set specific to the methylated DNA and un-methylated DNA were purchased from GeneChem (Shanghai, China). The primer sequences $\left(5^{\prime}-3^{\prime}\right)$ were shown as follows: PPAR $\alpha$ (Methylation): forward: AGAGTAGTAGAG TCGGGTTTATCGA; reverse: GAAACGAAACTA AATTCGAAACG. PPAR $\alpha$ (Unmethylation): forward: AGAGTAGTAGAGTTGGGTTTATTGA; reverse: AAAACAAAACTAAATTCAAAACAAA.

\section{Cell transfection}

The full length of PPAR $\alpha$ generated from genome DNA of HRCPs was subcloned into the vector pCEP4, generating the vector pCEP4-PPAR $\alpha$ (GeneChem). The empty pCEP4-NC vector served as control (vector1). The vector pcDNA3.1-DNMT1 overexpressed DNMT1, and the corresponding empty vector pcDNA3.1-NC (vector2) were constructed by GeneChem. Small interference RNA (siRNA) specifically targeting PPAR $\alpha$ (si-PPAR $\alpha-1$ and si-PPAR $\alpha-2$ ) or DNMT1 (si-DNMT1-1 and siDNMT1-2), and the corresponding NC (siRNA) were purchased from GeneChem. HRCPs $\left(100 \mu \mathrm{L} ; 1-5 \times 10^{4}\right.$ cells) were transfected with $75 \mathrm{ng}$ siRNA/miRNA using $3 \mu \mathrm{L}$ HiPerFect Transfection Reagent (Qiagen, Hilden, Germany), or transfected with $2 \mu \mathrm{g}$ vector using $2 \mu \mathrm{L}$ Lipofectamine 2000 Reagent (Invitrogen, Carlsbad, CA, USA) as the protocol described. After $48 \mathrm{~h}$ of transfection, the modified HRCPs were collected and stored at $-20{ }^{\circ} \mathrm{C}$ for further use.

\section{Gene expression}

Quantitative real-time PCR (qRT-PCR) was used to measure the gene expression in HRCPs and mouse retinal tissues. TRIzol reagent (Invitrogen) was used to extract total RNA from HRCPs and mouse retinal tissues. RNA integrity was examined by $1.5 \%$ agarose gel electrophoresis. RNA was reverse transcribed using PrimeScript ${ }^{\mathrm{TM}}$ RT reagent Kit (Takara, Tokyo, Japan) to synthesis complementary DNA. QRT-PCR was performed applying TB Green ${ }^{\circledR}$ Premix Ex Taq ${ }^{\text {TM }}$ II (Tli RNaseH Plus) (Takara) on an ABI Prism 7000 system (Thermo Fisher Scientific, Waltham, MA, USA). The relative expression of genes was analyzed using $2^{-\Delta \Delta C T}$ method.

\section{Protein expression}

Protein expression in HRCPs and mouse retinal tissues was examined by performing western blot (WB) assay. Total protein was extracted from HRCPs and mouse retinal tissues using Total Protein Extraction Kit (Solarbio) as the introduction described. BCA Protein Assay Kit (Solarbio) was used to examine the concentration of proteins. Protein samples were separated by $10 \%$ SDS-PAGE electrophoresis. Subsequently, the separated proteins were transferred onto polyvinylidene fluoride membranes (Merck Millipore). After blocked with 5\% skim milk, the membranes were incubated with the primary antibodies, PPAR $\alpha$, DNMT1, DNMT3A or DNMT3B (1:1000; Proteintech, Wuhan, China), at $4{ }^{\circ} \mathrm{C}$ for $12 \mathrm{~h}$. Next, the membranes were incubated with the horseradish peroxidase-conjugated secondary antibody (1:5000; Proteintech). $\beta$-actin antibody (1:5000; Proteintech) was used as a reference protein for normalization. The data were analyzed by Image J software.

\section{Cell apoptosis}

Apoptosis of HRCPs was examined applying Annexin V-FITC/PI Apoptosis Detection Kit (YEASEN, Shanghai, China). HRCPs were collected and washed with phosphate buffer saline (PBS) for several times. HRCPs were resuspended in $100 \mu \mathrm{L} 1 \times$ Binding Buffer. The cell suspension was incubated with $5 \mu \mathrm{L}$ Annexin V-FITC and $10 \mu \mathrm{L}$ PI staining solution at darkness for $15 \mathrm{~min}$. Subsequently, the cell suspension was mixed with $400 \mu \mathrm{L}$ of $1 \times$ Binding Buffer and put on ice. Cell apoptosis was determined by flow cytometry (BD Biosciences, San Jose, CA, USA) in an hour.

\section{Detection of intracellular reactive oxygen species (ROS)}

The levels of ROS in HRCPs were examined using Reactive Oxygen Species Assay Kit (Solarbio) as the protocol of the manufacturer. HRCPs were seeded in 24-well plates at a concentration of $2 \times 10^{4}$ cells/well and cultured for $24 \mathrm{~h}$. HRCPs were incubated with $1 \mathrm{~mL}$ DCFH-DA $(10 \mu \mathrm{M})$ at $37^{\circ} \mathrm{C}$ for $20 \mathrm{~min}$. The fluorescence intensity of the HRCPs was observed by confocal laser scanning microscope (LEICA, Wetzlar, Germany). Detection conditions: excitation wavelength $504 \mathrm{~nm}$, emission wavelength $529 \mathrm{~nm}$, and the grating width of the excitation and emission wavelengths was $5 \mathrm{~nm}$. 


\section{The interaction between DNMT1 and PPARa promoter} The interaction between DNMT1 and PPAR $\alpha$ promoter was examined by Chromatin Immunoprecipitation (ChIP) assay using Magna ChIP A/G Chromatin Immunoprecipitation Kit (Merck Millipore). In brief, HRCPs were fixed with $1 \%$ formaldehyde and glycine for $10 \mathrm{~min}$ to generate DNA-protein cross-links. The DNA-protein cross-links were degraded to chromatin fragments by sonication on ice for $3 \mathrm{~min}$. The chromatin fragments were incubated with anti-PPAR $\alpha$ (1:1000; Proteintech) or anti-IgG (1:2000; Proteintech) for immunoprecipitation. An aliquot of cell lysates served as input DNA control. The precipitated DNA was quantified by performing qRT-PCR. The primer sequences $\left(5^{\prime}-3^{\prime}\right)$ of PPAR $\alpha$ were shown as follows: forward: AGAGTAGTAGAGTTGGGTTTATTGA; reverse: AAAACAAAACTAAATTCAAAACAAA.

\section{Histological examination}

Retinal tissues were separated from mice, and then fixed with $4 \%$ paraformaldehyde, and embedded in paraffin. After deparaffin and rehydration, $4 \mu \mathrm{m}$ paraffin sections were obtained for histological examination. Subsequently, paraffin sections were stained using hematoxylin-eosin (HE) staining kit (Solarbio) to examine the damage of retinal tissues following the instruction of the manufacturer.

\section{Statistical analysis}

Each assay was performed for three times. All data reported as mean \pm standard deviation. SPSS 22.0 statistical software (IBM, Armonk, NY, USA) was used for statistical analysis. Two-tailed Student's $t$ test and one-way ANOVA were used to analyze the statistical difference. $P<0.05$ was considered as a significant difference.

\section{Results}

HG promoted PPARa methylation and apoptosis of HRCPs. Previously, we have initially confirmed the role of PPAR $\alpha$ in DR development. Whether PPAR $\alpha$ methylation is associated with DR remains unknown. Here, we further investigated the biological role of PPAR $\alpha$ methylation in DR. We first examined the methylation levels of PPAR $\alpha$ in HG-treated HRCPs by MSP assay, showing that the methylation levels of PPAR $\alpha$ were enhanced in HRCPs in the presence of HG (Fig. 1A). Next, we assessed the gene and protein expression of PPAR $\alpha$ in

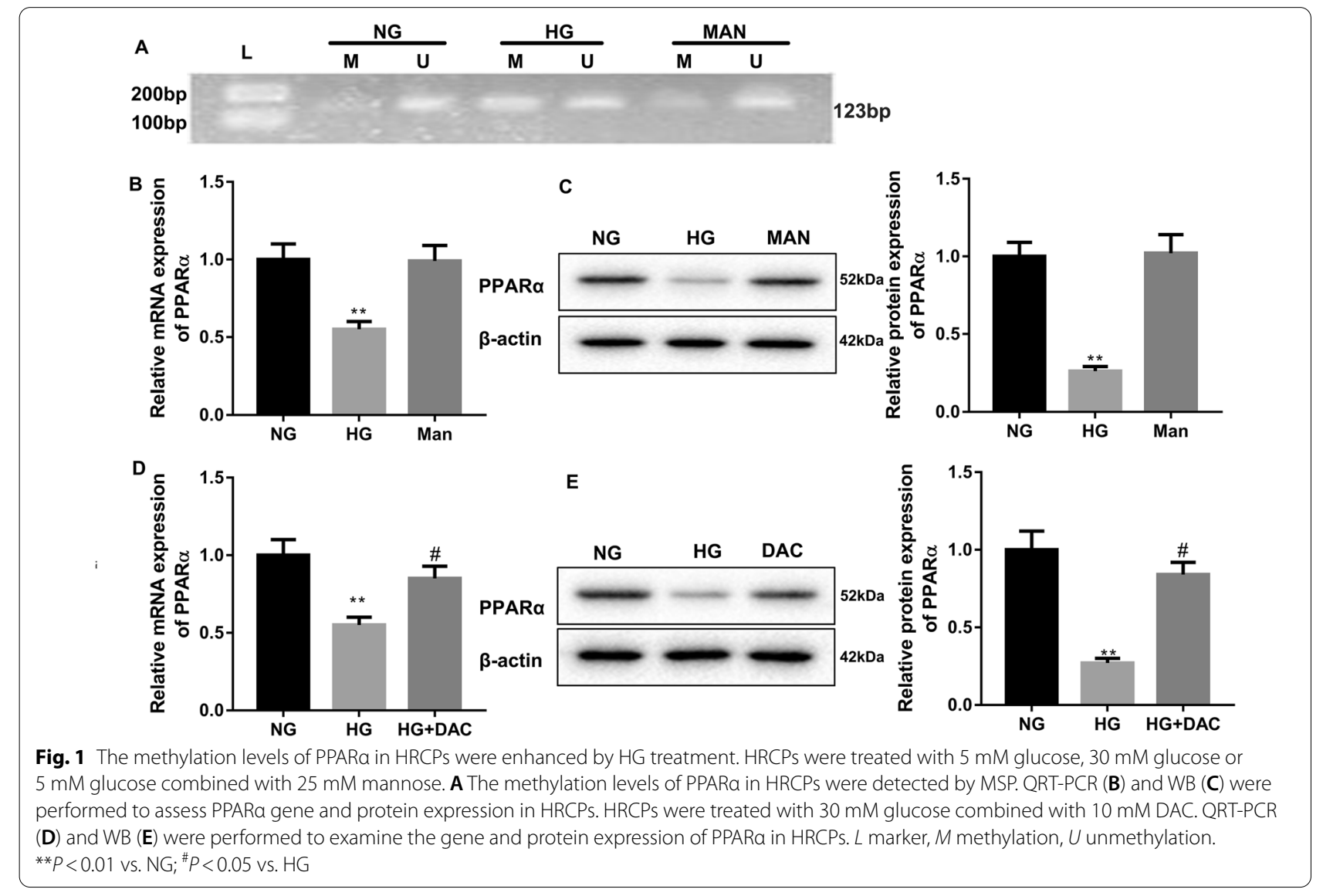


HRCPs by qRT-PCR and WB. HG treatment notably repressed the gene and protein expression of PPAR $\alpha$ in HRCPs as compared with NG group (Fig. 1B, C). There was no significant difference in the methylation and expression of PPAR $\alpha$ between NG and Mannose groups (Fig. 1B, C). Subsequently, HG-treated HRCPs were incubated with DAC to inhibit DNA methyltransferase. QRT-PCR and WB data revealed that HG treatment caused a down-regulation of PPAR $\alpha$ in HRCPs, which was partly rescued by DAC treatment (Fig. 1D, E). Moreover, flow cytometry was performed to estimate apoptosis of HRCPs. HG treatment aggravated apoptosis of HRCPs with respect to NG group. Apoptosis of HG-treated HRCPs was decreased in the presence of
DAC (Fig. 2A, C). Furthermore, we estimated the levels of ROS in HRCPs by DCFH-DA fluorescent probe, showing that HG treatment led to a boost in the levels of ROS in HRCPs, which was partly abolished by DAC treatment (Fig. 2B, D). Thus, these findings showed that HG enhanced PPAR $\alpha$ methylation and apoptosis of HRCPs.

\section{DNMT1 knockdown promoted PPARa expression} and repressed HG-induced apoptosis in HRCPs

To determine the mechanism of PPAR $\alpha$ methylation in HG-treated HRCPs, we assessed which methyltransferase (DNMT1, DNMT3A, DNMT3B) participated in the methylation of PPAR $\alpha$ in HG-treated HRCPs

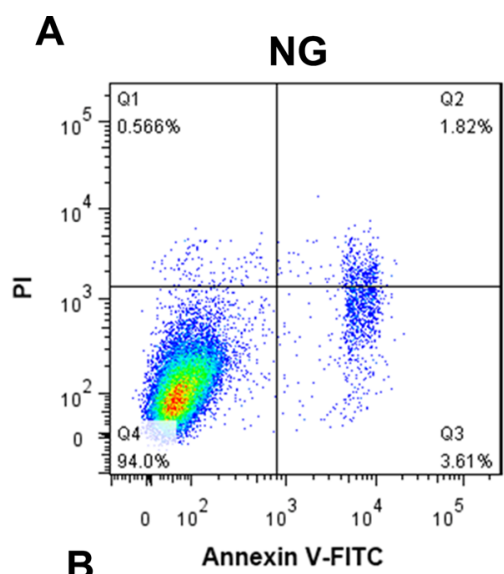

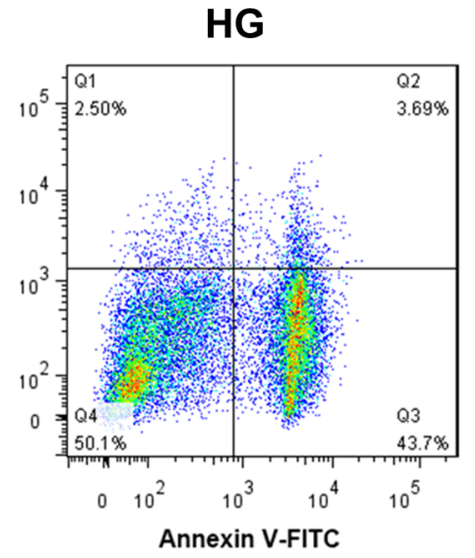

HG

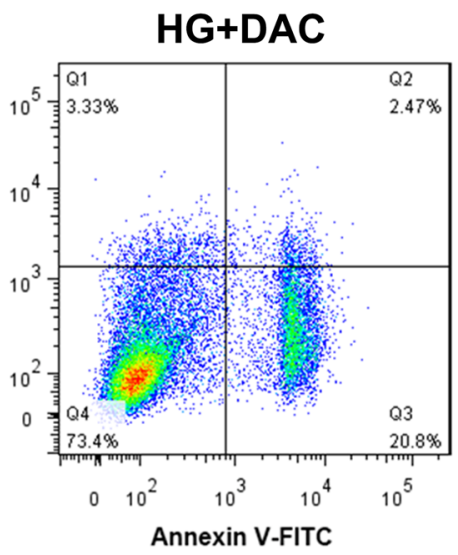

$H G+D A C$
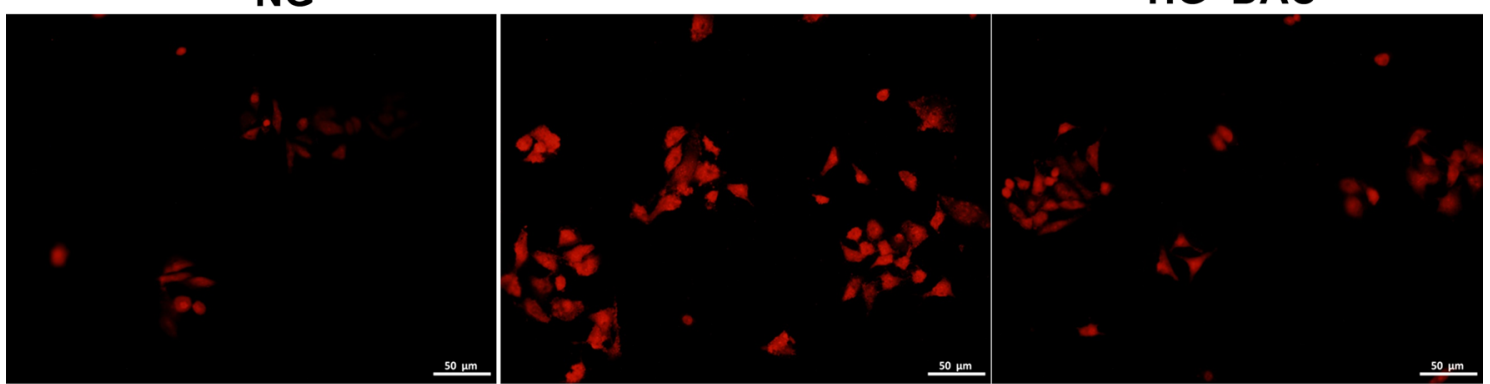

C

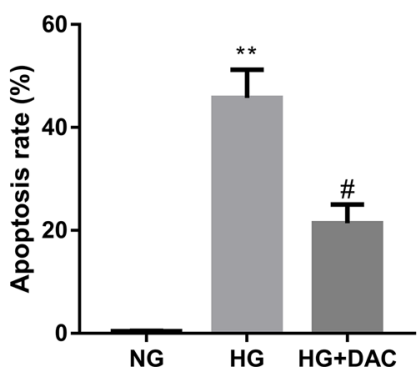

D

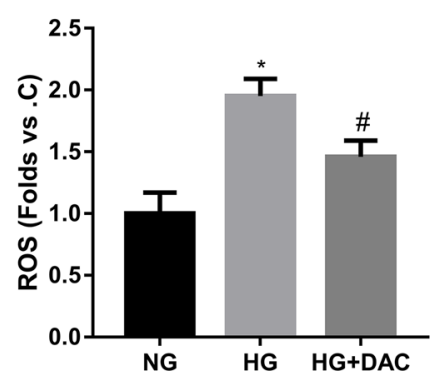

Fig. 2 DAC treatment reduced apoptosis and the leves of ROS in HG-treated HRCPs. HRCPs were treated with $30 \mathrm{mM}$ glucose combined with 10 mM DAC. A, C Flow cytometry was performed to estimate apoptosis of HRCPs. B, D The levels of ROS in HRCPs was detected by DCFH-DA fluorescent probe. ${ }^{*} P<0.05,{ }^{* *} P<0.01$ vs. NG; ${ }^{*} P<0.05$ vs. $\mathrm{HG}$ 

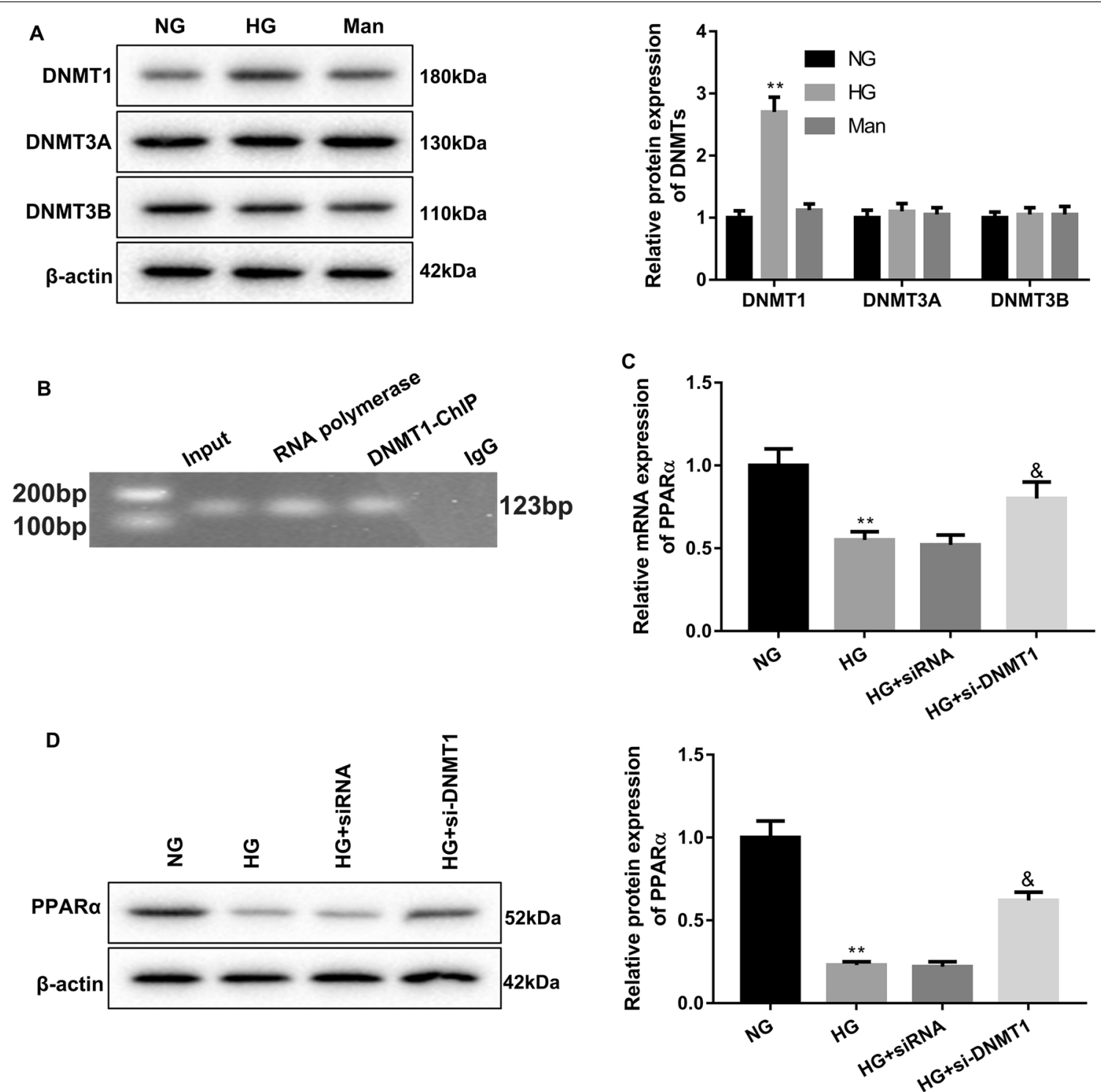

Fig. 3 DNMT1 knockdown promoted PPARa expression in HG-treated HRCPs. HRCPs were treated with $5 \mathrm{mM}$ glucose, $30 \mathrm{mM}$ glucose or 5 mM glucose combined with $25 \mathrm{mM}$ mannose. A WB was performed to assess the expression of DNMT1, DNMT3A and DNMT3B in HRCPs. B The interaction between DNMT1 and PPARa promoter was examined by ChIP assay. HRCPs were transfected with si-DNMT1 or siRNA, and then treated with $30 \mathrm{mM}$ glucose. QRT-PCR (C) and WB (D) were performed to assess PPARa gene and protein expression in HRCPs. ${ }^{*} P<0.01 \mathrm{vs}$. NG; ${ }^{\&} P<0.05$ vs. $H G+$ siRNA

by WB analysis. Figure 3A showed that HG significantly enhanced the expression of DNMT1 in HRCPs as compared with NG group. However, HG had no effect on the expression of DNMT3A and DNMT3B in HRCPs (Fig. 3A). Subsequently, we verified the relationship between DNMT1 and PPAR $\alpha$ promoter by ChIP assay, indicating that DNMT1 interacted with PPAR $\alpha$ promoter (Fig. 3B). Moreover, we silenced DNMT1 in HRCPs by transfection of si-DNMT1 or si-DNMT1-2. WB data showed that DNMT1 protein was severely decreased in HRCPs in the presence of si-DNMT1-1 and si-DNMT1-2, especially si-DNMT1-2 (Additional file 1: Figure S1). Thus, si-DNMT1-2 was used to silence DNMT1 in HRCPs. The DNMT1-silenced HRCPs were treated with HG. We examined the influence of DNMT1 deficiency on PPAR $\alpha$ expression in HRCPs. QRT-PCR and WB data showed that HG led to a down-regulation of PPAR $\alpha$ in HRCPs, which was partly rescued by DNMT1 deficiency (Fig. 3C, D). In addition, we assessed the effect of DNMT1 knockdown on apoptosis and ROS levels in 


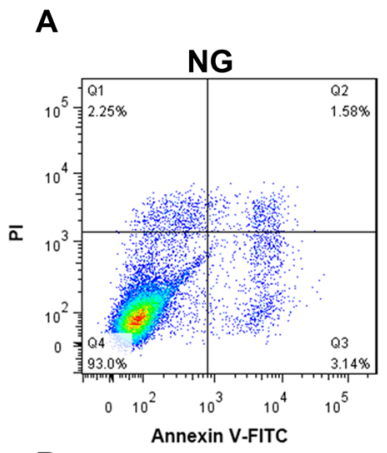

B
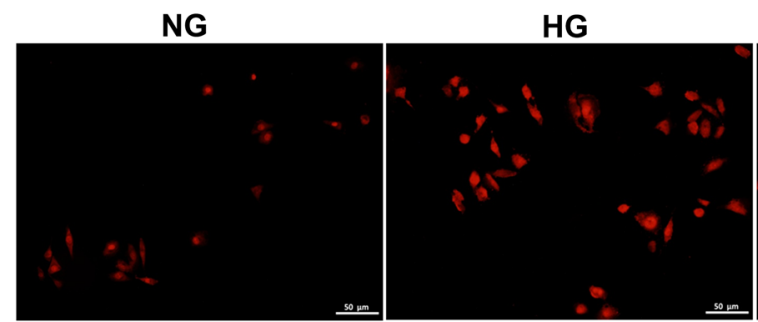

C

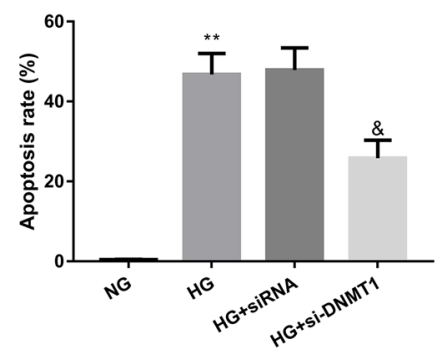

HG

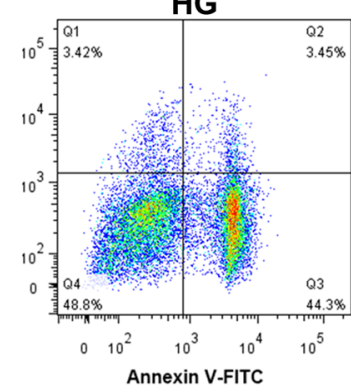

HG

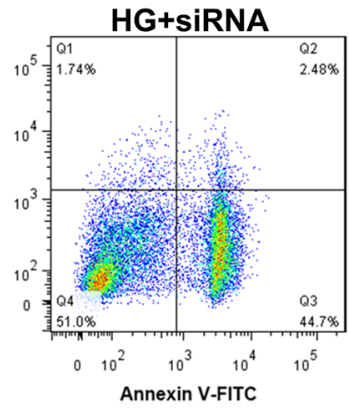

HG+siRNA

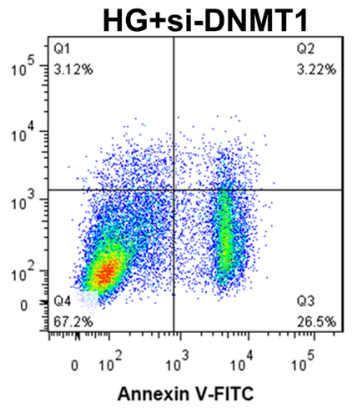

HG+si-DNMT1

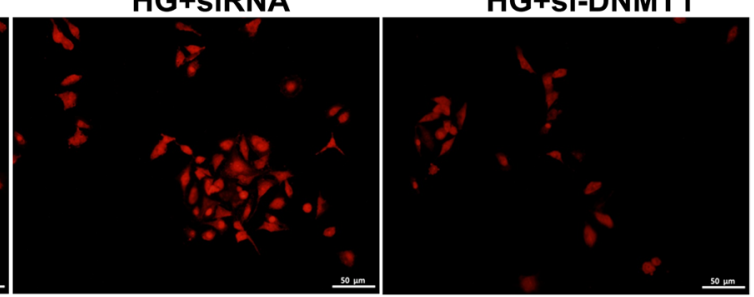

D

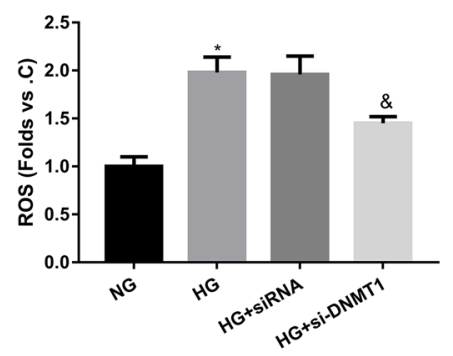

Fig. 4 DNMT1 knockdown repressed apoptosis and the levels of ROS in HG-treated HRCPs. HRCPs were transfected with si-DNMT1 or siRNA, and then treated with $30 \mathrm{mM}$ glucose. A, C Flow cytometry was performed to estimate apoptosis of HRCPs. B, D The levels of ROS in HRCPs was detected by DCFH-DA fluorescent probe. ${ }^{*} P<0.05,{ }^{* *} P<0.01$ vs. NG; ${ }^{\&} P<0.05$ vs. HG + siRNA

HRCPs. The results of flow cytometry and DCFH-DA fluorescent probe showed that apoptosis and the levels of ROS in HG-treated HRCPs were notably increased with respect to NG group. HG treatment-mediated increase of apoptosis and ROS levels in HRCPs was repressed by DNMT1 silencing (Fig. 4A-D). Thus, these data suggested that HG-induced PPAR $\alpha$ methylation in HRCPs was regulated by DNMT1.

\section{PPARa overexpression repressed apoptosis of HRCPs, which was rescued by DNMT1 up-regulation}

We further explored the biological role of DNMT1 in regulating PPAR $\alpha$ expression and apoptosis in HRCPs. HRCPs were transfected with pCEP4-PPAR $\alpha$ or si-PPAR $\alpha$ for up-regulation or down-regulation of PPAR $\alpha$. The data of qRT-PCR revealed that the expression of PPAR $\alpha$ was enhanced in HRCPs after transfected with pCEP4PPAR $\alpha$ (Fig. 5A). The expression of PPAR $\alpha$ was severely decreased in HRCPs in the presence of si-PPAR $\alpha-1$ and
si-PPAR $\alpha-2$, especially si-PPAR $\alpha-1$ (Fig. 5A, B). We then treated HRCPs with $\mathrm{HG}$ and estimated the effect of PPAR $\alpha$ overexpression or down-regulation on apoptosis and ROS levels of the HRCPs. Figure 5C, D showed that PPAR $\alpha$ up-regulation caused a decrease of apoptosis in HRCPs, whereas PPAR $\alpha$ deficiency enhanced apoptosis of HRCPs. The levels of ROS in HRCPs was reduced by PPAR $\alpha$ overexpression, and increased by PPAR $\alpha$ silencing (Fig. 5E, F). In addition, HRCPs were co-transfected with pCEP4-PPAR $\alpha$ and pcDNA3.1-DNMT1, and then treated with HG. The results obtained from qRT-PCR and WB revealed that PPAR $\alpha$ overexpression enhanced the gene and protein expression of PPAR $\alpha$ in HRCPs. The gene and protein expression of PPAR $\alpha$ in HRCPs was severely down-regulated in the presence of pCEP4PPAR $\alpha$ and pcDNA3.1-DNMT1 (Fig. 6A-C). Furthermore, flow cytometry and DCFH-DA fluorescent probe were used to estimate apoptosis and the levels of ROS in HRCPs. PPAR $\alpha$ up-regulation reduced apoptosis and the 
A

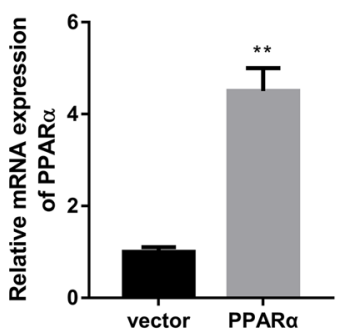

D

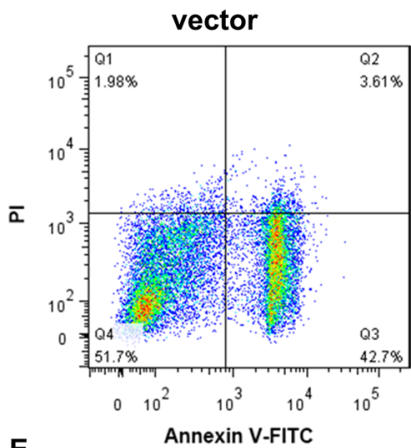

E
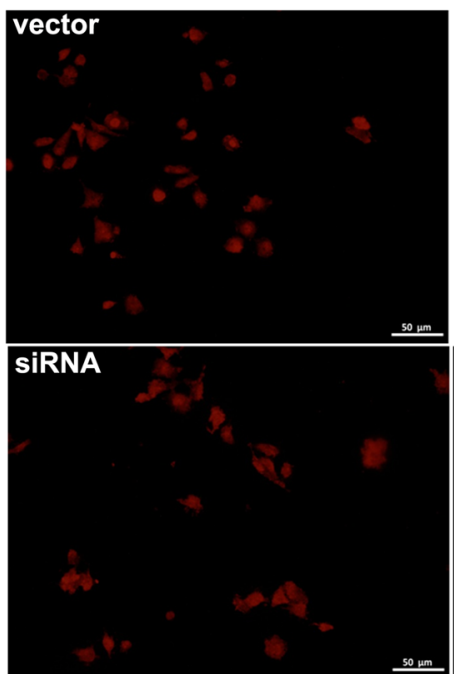
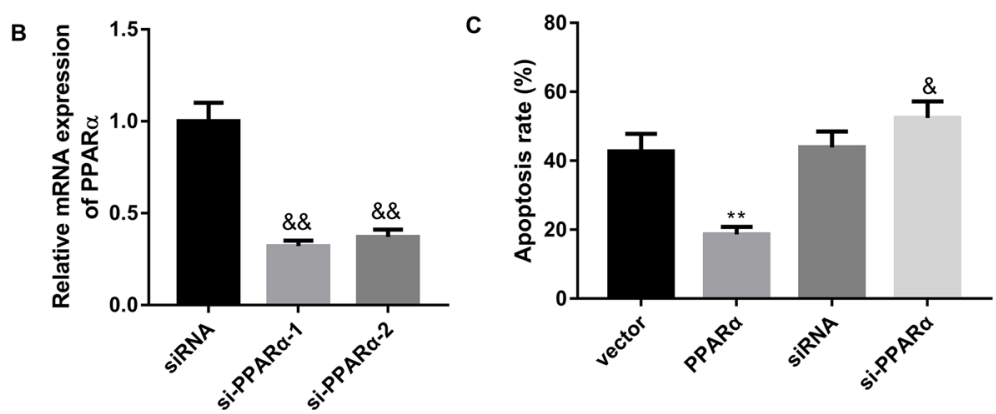

PPARa
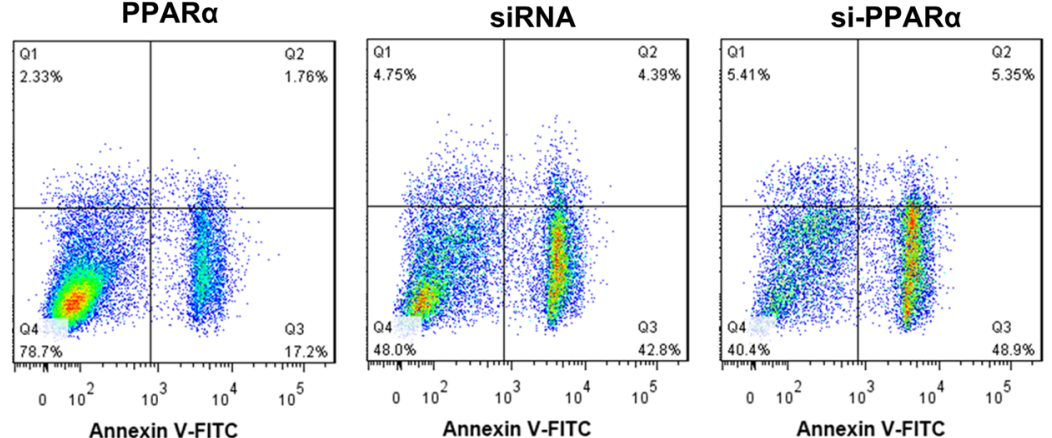

Annexin V-FITC

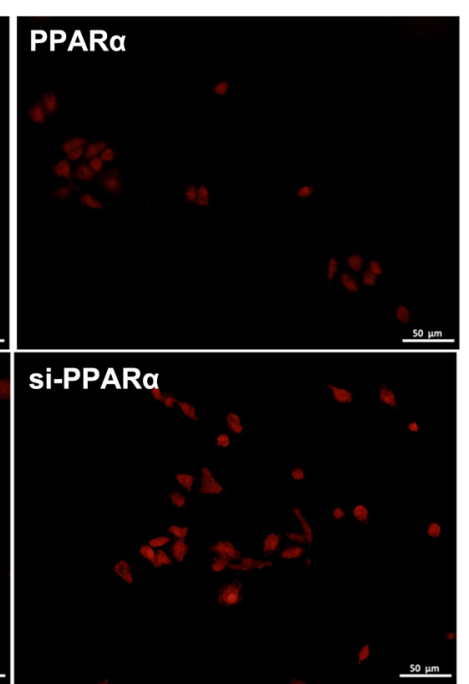

F

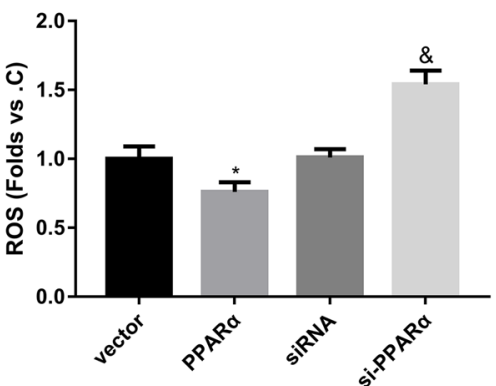

Fig. 5 PPARa overexpression repressed apoptosis and ROS levels in HG-treated HRCPs. HRCPs were transfected with pCEP4-PPARa, pCEP4-NC, si-PPARa (si-PPARa-1 and si-PPARa-2) or siRNA. A, B QRT-PCR was performed to assess the expression of PPARa in HRCPs. The modified HRCPs were treated with $30 \mathrm{mM}$ glucose. C, D Flow cytometry was performed to estimate apoptosis of HRCPs. E, F The levels of ROS in HRCPs was detected by DCFH-DA fluorescent probe. ${ }^{*} P<0.05,{ }^{* *} P<0.01$ vs. Vector; ${ }^{\&} P<0.05,{ }^{\&} \&<0.01$ vs. siRNA

levels of ROS in HRCPs. The inhibiting effect of PPAR $\alpha$ overexpression on apoptosis ROS levels in HRCPs was partly abolished by DNMT1 up-regulation (Fig. 6D-G). Taken together, these data confirmed that DNMT1 upregulation abolished the inhibiting effect of PPAR $\alpha$ overexpression on apoptosis of HRCPs.
DAC treatment attenuated the damage of retinal tissues in DR mice by inhibiting the methylation levels of PPARa We examined the effect of PPAR $\alpha$ methylation on pathological changes of retinal tissues in DR mice. We constructed DR mouse model by intraperitoneal injection of STZ, and the DR mice were received DAC treatment to inhibit DNA methyltransferase. We observed the pathological changes of retinal tissues in mice by HE staining, 
A
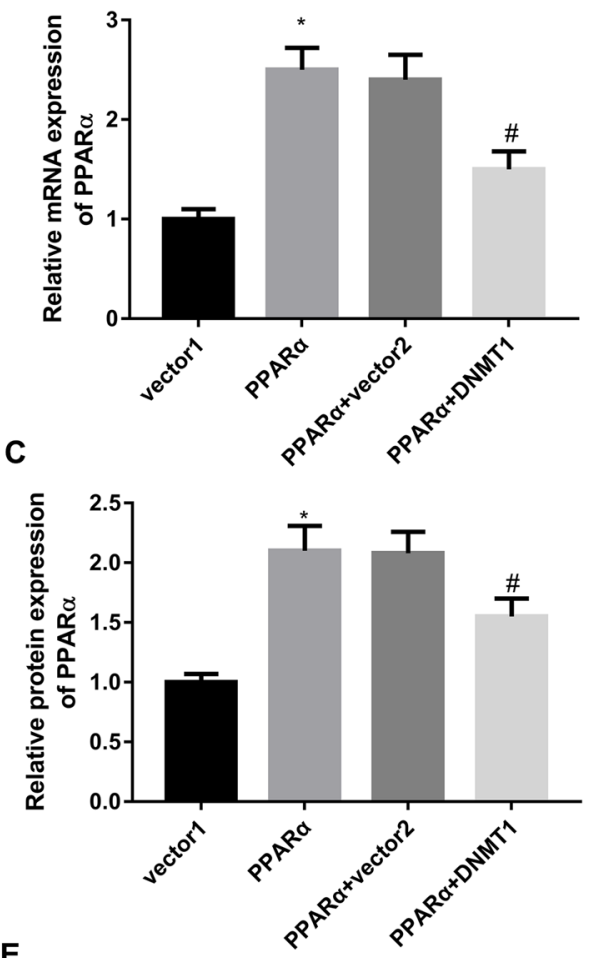

$\mathbf{E}$
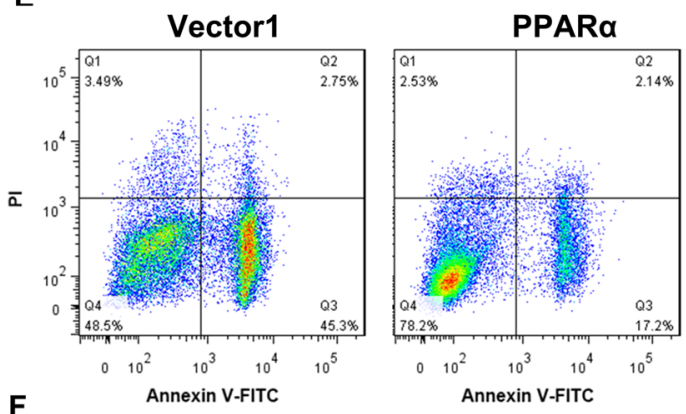

B

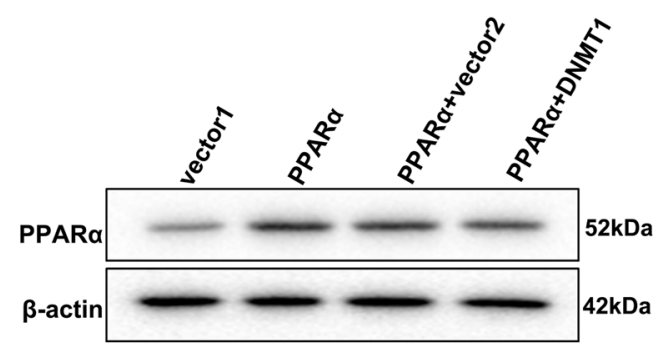

D

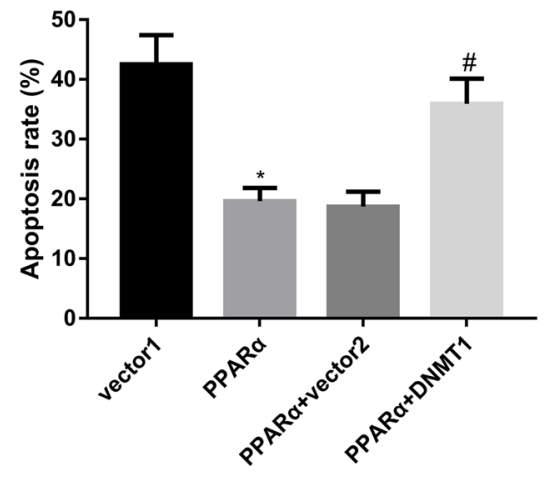

PPARa+vector2

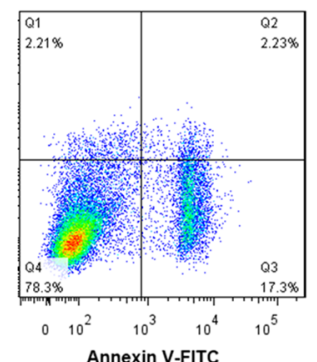

PPAR $\alpha+D N M T 1$
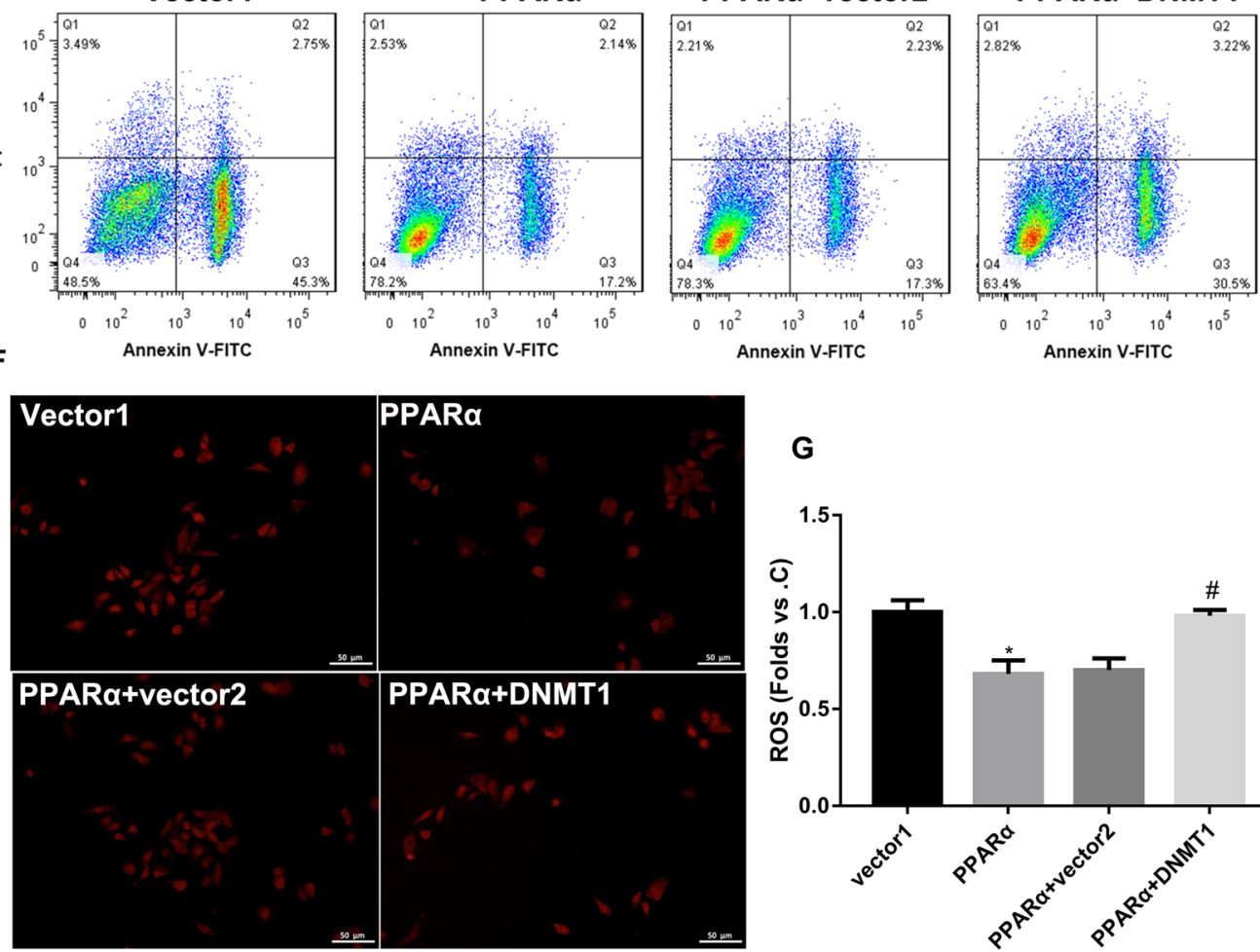

G

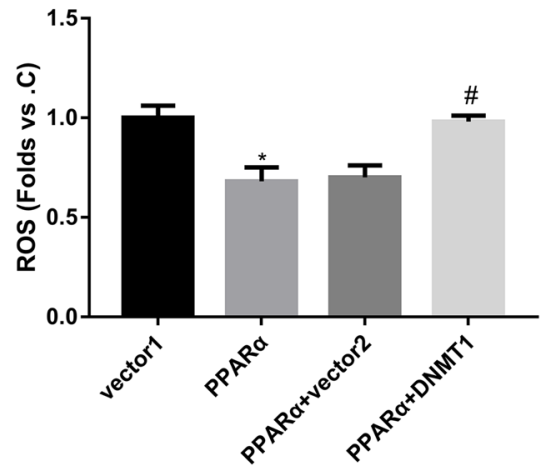

Fig. 6 DNMT1 overexpression reversed the impact of PPARa overexpression on apoptosis and ROS levels in HG-treated HRCPs. HRCPs were co-transfected with pCEP4-PPARa, pCEP4-NC and pcDNA3.1-DNMT1 or pCDNA3.1-NC, and then treated with 30 mM glucose. QRT-PCR (A) and WB (B, C) were performed to assess PPARa gene and protein expression in HRCPs. D, E Flow cytometry was performed to estimate apoptosis of HRCPs. $\mathbf{F}$, G The levels of ROS in HRCPs was detected by DCFH-DA fluorescent probe. ${ }^{*} P<0.05$ vs. Vector $1 ; ~ * P<0.05$ vs. PPARa + vector2 
showing that the control mice displayed a normal retinal tissue structure. The layers of retinal tissues were arranged regularly and clearly. Cell morphology was normal and compact. In STZ-induced DR mice, the layers of retinal tissues were loose and irregular. The number of ganglion cells was reduced, and the ganglion cell layer displayed obvious vacuolar degeneration. Cells in the inner and outer nuclear layers were arranged disorderly, and the cell density was reduced. However, the structure of each layer of retinal tissues was regular in STZinduced DR mice following DAC treatment. Cells in the inner and outer nuclear layers were arranged neatly, and the cell density was increased in STZ-induced DR mice in the presence of DAC (Fig. 7A). Then, the methylation levels of PPAR $\alpha$ in retinal tissues were detected by MSP assay. We found that the methylation levels of PPAR $\alpha$ in DR mice were significantly enhanced with respect to control mice. Compared with DR mice, DAC treatment notably repressed the methylation levels of PPAR $\alpha$ in mice (Fig. 7B). In addition, qRT-PCR and WB were performed to examine the effect of DAC treatment on PPAR $\alpha$ expression in DR mice. PPAR $\alpha$ mRNA and protein were notably down-regulated in retinal tissues of DR mice. However, the mRNA and protein expression of PPAR $\alpha$ was increased in mice following treatment of DAC (Fig. 7C, D). Thus, these data demonstrated that DAC treatment attenuated the damage of retinal tissues in DR mice by inhibiting the methylation levels of PPAR $\alpha$.

\section{Discussion}

In recent years, scholars have conducted in-depth researches on the mechanism of DNA methylation in the progression of DR. Maghbooli et al. have compared the levels of global DNA methylation between DR patients and diabetic patients without retinopathy, showing that DR patients display a higher global DNA methylation levels [31]. Thus, the levels of global DNA methylation may be a biomarker for DR. Previous study has confirmed that MnTBAP promotes the levels of $5 \mathrm{mC}$ and inhibits the interaction between MMP-9 promoter and DNMT1, thereby regulating the transcription of MMP-9 and repressing mitochondria damage in DR mice [32].

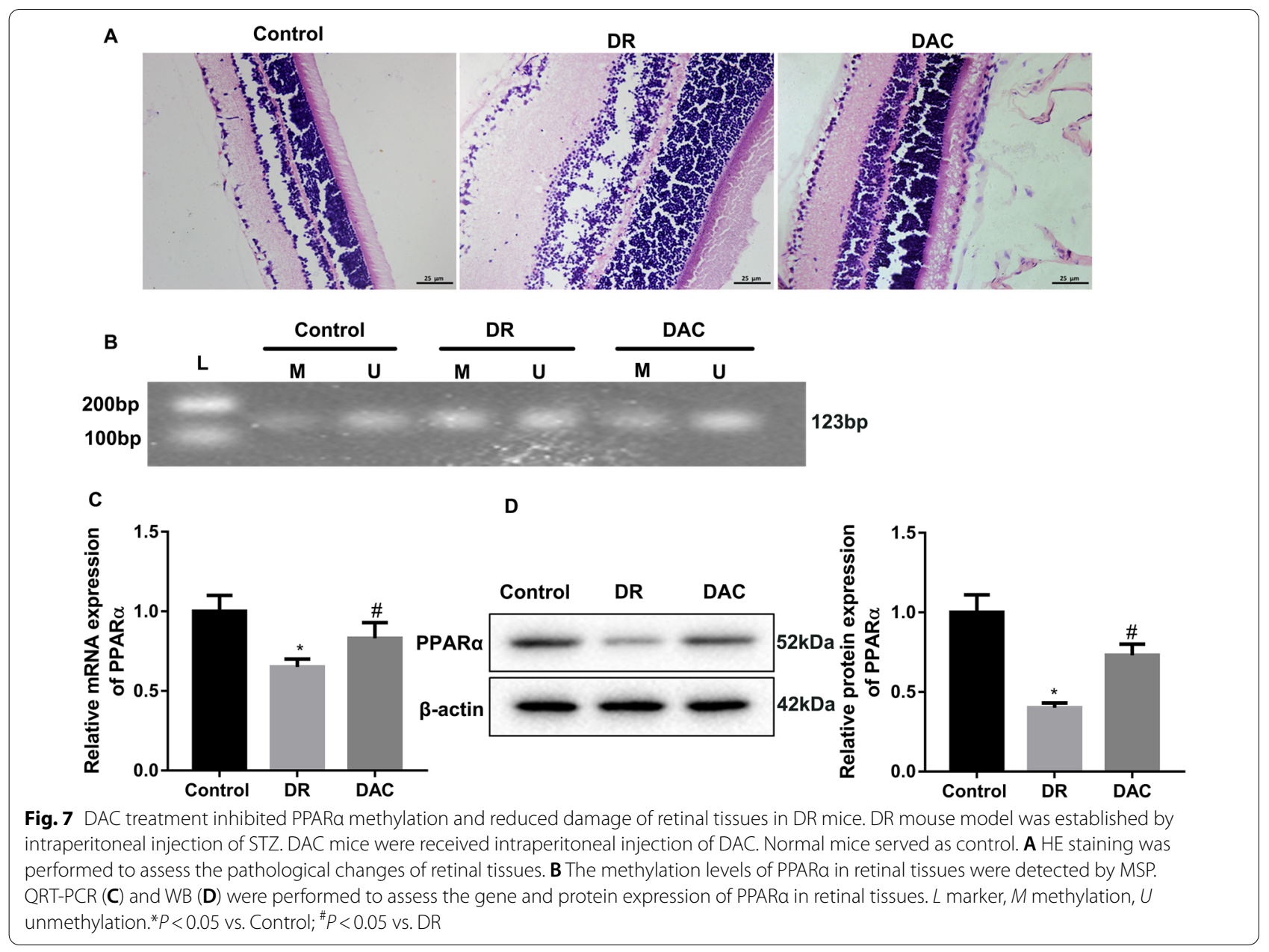


The transcription of MMP-9 in the retina is regulated by DNA methylation-hydroxymethylation process, thereby maintaining the homeostasis of mitochondria and inhibiting the occurrence and development of DR [33]. However, little is known about PPAR $\alpha$ in DR. In the present work, we revealed the function of PPAR $\alpha$ methylation in DR. HG treatment induced an increase of PPAR $\alpha$ methylation levels and a down-regulation of PPAR $\alpha$ in HRCPs. Moreover, HG treatment enhanced apoptosis and ROS levels in HRCPs. The influence conferred by HG treatment was effectively abolished by treatment of DNA methylation inhibitor, DAC. These data suggested that PPAR $\alpha$ methylation was associated with HG-induced increase of apoptosis and ROS levels in HRCPs. Additionally, $\mathrm{Qu}$ et al. have confirmed the inhibiting effect of DAC on apoptosis of cloned embryos [34]. DAC represses apoptosis and oxidative stress of $\mathrm{H}_{2} \mathrm{O}_{2}$-treated SRA01/04 cells [35]. Thus, DAC may inhibit apoptosis and ROS levels in HRCPs.

PPAR $\alpha$ methylation participates in the progression of various diseases. The steatotic hepatocyte models and non-alcoholic fatty liver disease rat models exhibit a down-regulation of PPAR- $\alpha$ and an increase of PPAR $\alpha$ methylation, which are partly rescued by DAC or curcumin treatment [36]. High fructose promotes the methylation levels of PPAR $\alpha$ and CPT1A in rat liver, suggesting that DNA methylation status of PPAR $\alpha$ and CPT1A is closely associated with the pathogenesis of fructoseinduced metabolic syndrome [37]. Betaine supplement alleviates hepatic triglyceride accumulation and improves antioxidant capacity in $\mathrm{ApoE}^{-/-}$mice, which attributes to inhibit PPAR $\alpha$ methylation and enhance PPAR $\alpha$ expression [38]. Homocysteine-mediated DNA methylation of PPAR $\alpha$ and PPAR $\gamma$ participates in the pathogenic mechanism of atherosclerosis [39]. In this work, we found that the expression of DNMT1 was enhanced in the HGinduced HRCPs, and DNMT1 interacted with PPAR $\alpha$ promoter. We concluded that HG induced DNMT1mediated PPAR $\alpha$ methylation in HRCPs. Moreover, DNMT1 knockdown enhanced the expression of PPAR $\alpha$ in HRCPs by reducing the methylation levels of PPAR $\alpha$. DNMT1 deficiency reduced HG-induced increase of apoptosis and ROS levels in HRCPs. Therefore, these results suggested that HG treatment enhanced apoptosis and ROS levels by promoting DNMT1-mediated PPAR $\alpha$ methylation in HRCPs.

DNM methyltransferase is an important enzyme family in epigenetics that catalyzes and maintains DNA methylation. DNMT1 is a key enzyme for DNA to perform replication and repair, and maintain its normal methylation [40]. DNMT1 is highly expressed in hair follicle stem cells, and DNMT1-mediated miR-214-3p methylation promotes adipogenesis of hair follicle stem cells via
MAPK1/p-ERK1/2 axis [41]. Long noncoding RNA PVT1 inhibits miR-18b-5p expression by recruiting DNMT1, and DNMT1 promotes miR-18b-5p methylation, thereby promoting gallbladder cancer proliferation [42]. These studies have confirmed the key role of DNMT1 in regulating DNA methylation of genes. However, whether PPAR $\alpha$ methylation is regulated by DNMT1 has not been reported. Our data revealed that DNMT1 interacted with PPAR $\alpha$ promoter, and repressed PPAR $\alpha$ expression in HRCPs. Moreover, the inhibiting effect of PPAR $\alpha$ overexpression on apoptosis and ROS levels in HRCPs was effectively rescued by DNMT1 overexpression. Thus, DNMT1 overexpression enhanced the methylation levels of PPAR $\alpha$ and reduced PPAR $\alpha$ expression, which contributed to elevate apoptotic cells and ROS levels in HRCPs. Finally, we constructed a DR mouse model by intraperitoneal injection of STZ, and verified the speculation by in vivo assays. The layers of retinal tissues in DR mice were loose and irregular. The number of ganglion cells was reduced, and the ganglion cell layer displayed obvious vacuolar degeneration. Cells in the inner and outer nuclear layers were arranged disorderly, and the cell density was reduced. Thus, the damage of the retinal tissues was manifested in the destruction of various layers of retina structure, which resulted in subsequent functional changes and vision loss. Many researches also have observed that the inner and outer nuclear layers are blurred, and the ganglion cell layer is destroyed in the retina of DR mice and rats [43-45]. A previous study has confirmed that there are changes in nerve fiber function before detectable microvascular changes appear in the fundus of diabetic patients, and retinal nerve function degeneration occurs in the early stage of DR [46]. The pathological changes of retinal tissues observed in our data also confirmed this view. Additionally, DAC treatment effectively reduced damage of retinal tissues in DR mice. DR mice exhibited a high methylation level of PPAR $\alpha$, and a down-regulation of PPAR $\alpha$, which was abrogated by DAC treatment-mediated inhibition of PPAR $\alpha$ methylation. This, these data demonstrated that DNMT1-mediated PPAR $\alpha$ methylation promoted apoptosis of HRCPs and aggravated damage of retinal tissues, thereby accelerating the progression of DR (Additional file 2: Figure S2).

Previous study has shown that DNMT1-mediated MEG3 methylation promotes endothelial-mesenchymal transition in DR, and thus facilitates DR development [21]. Biswas et al. have demonstrated that inhibition of MALAT1 methylation enhances the levels of inflammatory factors in human retinal endothelial cells, which contributes to accelerate DR progression [47]. Thus, DNA methylation has a complex function in the development of DR. The specific mechanism of DNA 
methylation in DR still needs further in-depth study. Additionally, inflammation and macrophage infiltration are closely associated with the development of DR $[48,49]$. This work only initially explored the effect of DNMT1-mediated PPAR $\alpha$ methylation on apoptosis and ROS in HRCPs. Whether PPAR $\alpha$ methylation can affect inflammation and macrophage infiltration in DR is still unclear, which is a shortcoming of our research. We will conduct research on this issue in future work.

\section{Conclusions}

In conclusion, our data demonstrate that DNMT1mediated PPAR $\alpha$ methylation promotes apoptosis of HRCPs and aggravates damage of retinal tissues in DR mice. Thus, this study may highlight novel insights into the pathogenic mechanisms of DR.

\section{Abbreviations}

ChIP: Chromatin immunoprecipitation; DAC: 5-Aza-2-deoxycytidine; DNMT1: DNA methyltransferase-1; DR: Diabetic retinopathy; FBS: Fetal bovine serum; HE: Hematoxylin-eosin; HG: High glucose; HRCPs: Human retinal capillary pericytes; Man: Mannose; MSP: Methylation-specific PCR; NG: Normal glucose; PBS: Phosphate buffer saline; PPARs: Peroxisome proliferator-activated receptors; qRT-PCR: Quantitative real-time PCR; ROS: Reactive oxygen species; siRNA: Small interference RNA; STZ: Streptozotocin; WB: Western blot.

\section{Supplementary Information}

The online version contains supplementary material available at https://doi. org/10.1186/s40659-021-00347-1.

Additional file 1: Figure $\mathbf{S 1}$. The protein expression of DNMT1 in HRCPS WB was performed to assess the protein expression of DNMT1 in HRCPs following transfection of si-DNMT1-1, si-DNMT1-2 or siRNA.

Additional file 2: Figure S2. Schematic representation of the functional role of PPARa in DR.

\section{Acknowledgements}

Not applicable.

\section{Authors' contributions}

$Y Z$ designed the study; $Y Z, X W, X Z, L D, D L, H X$ performed the study; $Y Z, H X$ analyzed the data; $Y Z$ drafted the paper. All authors read and approved the final manuscript.

\section{Funding}

This work was supported by grants from National Natural Science Foundation of China (No. 81600756).

\section{Availability of data and materials}

The datasets used and/or analysed during the current study are available from the corresponding author on reasonable request.

\section{Declarations}

Ethics approval and consent to participate

All protocols were authorized by the Ethics Committee of Xiangya Hospital, Central South University (Changsha, China). (No. 201904609).
Consent for publication

Not applicable.

\section{Competing interests}

The authors declare no conflicts of interest.

\section{Author details}

${ }^{1}$ Eye Center of Xiangya Hospital, Central South University, No. 87 Xiangya Road, Hunan 410008 Changsha, China. ${ }^{2}$ Department of Ophthalmology, The First Hospital of Changsha, 311 Yingpan Road, Hunan, Changsha, China.

Received: 17 November 2020 Accepted: 21 July 2021

Published online: 06 August 2021

\section{References}

1. Zang J, Guan G. Study of pigment epithelium-derived factor in pathogenesis of diabetic retinopathy. Eye science. 2015;30(2):81-8.

2. Xu Y, Wang L, He J, Bi Y, Li M, Wang T, Wang L, Jiang Y, Dai M, Lu J, et al. Prevalence and control of diabetes in Chinese adults. JAMA. 2013;310(9):948-59.

3. Simó R, Stitt A, Gardner T. Neurodegeneration in diabetic retinopathy: does it really matter? Diabetologia. 2018;61(9):1902-12.

4. Collaboration NRF. Worldwide trends in diabetes since 1980: a pooled analysis of 751 population-based studies with 4.4 million participants. Lancet. 2016;387(10027):1513-30.

5. Yau J, Rogers S, Kawasaki R, Lamoureux E, Kowalski J, Bek T, Chen S, Dekker J, Fletcher A, Grauslund J, et al. Global prevalence and major risk factors of diabetic retinopathy. Diabetes Care. 2012;35(3):556-64.

6. Hammes HP. Pericytes and the pathogenesis of diabetic retinopathy. Horm Metab Res. 2005. https://doi.org/10.1055/s-2005-861361.

7. Jo D, Yun J, Cho C, Kim J, Kim J, Cho C. Interaction between microglia and retinal pigment epithelial cells determines the integrity of outer bloodretinal barrier in diabetic retinopathy. Glia. 2019:67(2):321-31.

8. Roy S, Kim D, Hernández C, Simó R, Roy S. Beneficial effects of fenofibric acid on overexpression of extracellular matrix components, COX-2, and impairment of endothelial permeability associated with diabetic retinopathy. Exp Eye Res. 2015;140:124-9.

9. Lechner J, O'Leary O, Stitt A. The pathology associated with diabetic retinopathy. Vision Res. 2017;139:7-14.

10. Nathan D. The diabetes control and complications trial/epidemiology of diabetes interventions and complications study at 30 years: overview. Diabetes Care. 2014:37(1):9-16.

11. Beulens J, Patel A, Vingerling J, Cruickshank J, Hughes A, Stanton A, Lu J, McG Thom S, Grobbee D, Stolk R. Effects of blood pressure lowering and intensive glucose control on the incidence and progression of retinopathy in patients with type 2 diabetes mellitus: a randomised controlled trial. Diabetologia. 2009;52(10):2027-36.

12. Miao F, Chen Z, Genuth S, Paterson A, Zhang L, Wu X, Li SM, Cleary P, Riggs A, Harlan DM, et al. Evaluating the role of epigenetic histone modifications in the metabolic memory of type 1 diabetes. Diabetes. 2014;63(5):1748-62.

13. Zhang $L$, Xia H, Han $Q$, Chen B. Effects of antioxidant gene therapy on the development of diabetic retinopathy and the metabolic memory phenomenon. Graefes Arch Clin Exp Ophthalmol. 2015;253(2):249-59.

14. Wang CL, Yang TL. Epidemiology and Preventive medicine: metabolic syndrome and diabetes: e0305 the effect of profilin-1 on vascular injury caused by advanced glycation end products. Heart. 2010;96(3):A96.

15. Zeng J, Chen B. Epigenetic mechanisms in the pathogenesis of diabetic retinopathy. Ophthalmologica. 2014;232(1):1-9.

16. Reddy MA, Zhang E, Natarajan R. Epigenetic mechanisms in diabetic complications and metabolic memory. Diabetologia. 2015;58(3):443-55.

17. Xie MY, Yang Y, Liu P, Luo Y, Tang SB. 5-aza-2'-deoxycytidine in the regulation of antioxidant enzymes in retinal endothelial cells and rat diabetic retina. Int J Ophthalmol. 2019;12(1):1-7.

18. Chen Z, Miao F, Paterson A, Lachin J, Zhang L, Schones D, Wu X, Wang J, Tompkins J, Genuth S, et al. Epigenomic profiling reveals an association between persistence of DNA methylation and metabolic memory in the DCCT/EDIC type 1 diabetes cohort. Proc Natl Acad Sci USA. 2016;113(21):E3002-11. 
19. Moore L, Le T, Fan G. DNA methylation and its basic function. Neuropsychopharmacology. 2013;38(1):23-38.

20. Jeltsch A, Jurkowska R. New concepts in DNA methylation. Trends Biochem Sci. 2014;39(7):310-8.

21. He Y, Dan Y, Gao X, Huang L, Lv H, Chen J. DNMT1-mediated IncRNA MEG3 methylation accelerates endothelial-mesenchymal transition in diabetic retinopathy through the PI3K/Akt/mTOR signaling pathway. Am J Physiol Endocrinol Metab. 2021;320(3):E598-608.

22. Mishra M, Kowluru RA. Epigenetic modification of mitochondrial DNA in the development of diabetic retinopathy. Invest Ophthalmol Vis Sci. 2015;56(9):5133-42.

23. Berger J, Moller DE. The mechanisms of action of PPARs. Annu Rev Med. 2002;53:409-35

24. Ramakrishnan SK, Khuder SS, Al-Share QY, Russo L, Abdallah SL, Patel PR, Heinrich G, Muturi HT, Mopidevi BR, Oyarce AM, et al. PPARa (peroxisome proliferator-activated receptor a) activation reduces hepatic CEACAM1 protein expression to regulate fatty acid oxidation during fasting-refeeding transition. J Biol Chem. 2016;291(15):8121-9.

25. Pawlak M, Lefebvre P, Staels B. Molecular mechanism of PPARa action and its impact on lipid metabolism, inflammation and fibrosis in nonalcoholic fatty liver disease. J Hepatol. 2015;62(3):720-33.

26. Rizvi YQ, Mehta CS, Oyekan A. Interactions of PPAR-alpha and adenosine receptors in hypoxia-induced angiogenesis. Vascul Pharmacol. 2013;59:144-51.

27. Ding L, Cheng R, Hu Y, Takahashi Y, Jenkins AJ, Keech AC, Humphries KM, Gu X, Elliott MH, Xia X, et al. Peroxisome proliferator-activated receptor a protects capillary pericytes in the retina. Am J Pathol. 2014;184(10):2709-20.

28. Hu Y, Chen Y, Ding L, He X, Takahashi Y, Gao Y, Shen W, Cheng R, Chen Q, Qi X, et al. Pathogenic role of diabetes-induced PPAR-a downregulation in microvascular dysfunction. Proc Natl Acad Sci USA. 2013;110(38):15401-6.

29. Lillycrop KA, Phillips ES, Jackson AA, Hanson MA, Burdge GC. Dietary protein restriction of pregnant rats induces and folic acid supplementation prevents epigenetic modification of hepatic gene expression in the offspring. J Nutr. 2005;135(6):1382-6.

30. Ge ZJ, Luo SM, Lin F, Liang QX, Huang L, Wei YC, Hou Y, Han ZM, Schatten $\mathrm{H}$, Sun QY. DNA methylation in oocytes and liver of female mice and their offspring: effects of high-fat-diet-induced obesity. Environ Health Perspect. 2014;122(2):159-64.

31. Maghbooli Z, Hossein-nezhad A, Larijani B, Amini M, Keshtkar A. Global DNA methylation as a possible biomarker for diabetic retinopathy. Diabetes Metab Res Rev. 2015;31(2):183-9.

32. Kowluru RA, Shan Y. Role of oxidative stress in epigenetic modification of MMP-9 promoter in the development of diabetic retinopathy. Graefes Arch Clin Exp Ophthalmol. 2017;255(5):955-62.

33. Kowluru RA, Shan Y, Mishra M. Dynamic DNA methylation of matrix metalloproteinase- 9 in the development of diabetic retinopathy. Lab Invest. 2016;96(10):1040-9.

34. Qu J, Wang $X$, Jiang $Y, L v X$, Song $X$, He H, Huan Y. Optimizing 5-aza$2^{\prime}$-deoxycytidine treatment to enhance the development of porcine cloned embryos by inhibiting apoptosis and improving DNA methylation reprogramming. Res Vet Sci. 2020;132:229-36.

35. Jiang S, Chen J.WRN inhibits oxidative stress-induced apoptosis of human lensepithelial cells through ATM/p53 signaling pathway and its expression is downregulated by DNA methylation. Mol Med. 2020;26(1):68.

36. Li YY, Tang D, Du YL, Cao CY, Nie YQ, Cao J, Zhou YJ. Fatty liver mediated by peroxisome proliferator-activated receptor-a DNA methylation can be reversed by a methylation inhibitor and curcumin. J Dig Dis. 2018;19(7):421-30.

37. Ohashi K, Munetsuna E, Yamada H, Ando Y, Yamazaki M, Taromaru N, Nagura A, Ishikawa H, Suzuki K, Teradaira R, et al. High fructose consumption induces DNA methylation at PPARa and CPT1A promoter regions in the rat liver. Biochem Biophys Res Commun. 2015;468:185-9.

38. Wang L, Chen L, Tan Y, Wei J, Chang Y, Jin T, Zhu H. Betaine supplement alleviates hepatic triglyceride accumulation of apolipoprotein $\mathrm{E}$ deficient mice via reducing methylation of peroxisomal proliferator-activated receptor alpha promoter. Lipids Health Dis. 2013;12:34.

39. Yideng J, Zhihong L, Jiantuan X, Jun C, Guizhong L, Shuren W. Homocysteine-mediated PPARalpha, gamma DNA methylation and its potential pathogenic mechanism in monocytes. DNA Cell Biol. 2008;27(3):143-50.

40. Cheng X, Blumenthal RM. Mammalian DNA methyltransferases: a structural perspective. Structure. 2008;16(3):341-50.

41. Jin F, Li M, Li X, Zheng Y, Zhang K, Liu X, Cai B, Yin G. DNMT1-mediated methylation inhibits microRNA-214-3p and promotes hair follicle stem cell differentiate into adipogenic lineages. Stem Cell Res Ther. 2020;11(1):444

42. Jin L, Cai Q, Wang S, Wang S, Wang J, Quan Z. Long noncoding RNA PVT1 promoted gallbladder cancer proliferation by epigenetically suppressing miR-18b-5p via DNA methylation. Cell Death Dis. 2020;11(10):871.

43. Song S, Bao S, Zhang C, Zhang J, Lv J, Li X, Chudhary M, Ren X, Kong L. Stimulation of AMPK prevents diabetes-induced photoreceptor cell degeneration. Oxid Med Cell Longev. 2021;2021: 5587340.

44. Jia J, Qiu D, Lu C, Wang W, Li N, Han Y, Tong P, Sun X, Wu M, Dai J. Transcriptome analysis of choroid and retina from tree shrew with choroidal neovascularization reveals key signaling moieties. Front Genet. 2021;12: 654955.

45. Liu X, Li J, Li X. miR-142-5p regulates the progression of diabetic retinopathy by targeting IGF1. Int J Immunopathol Pharmacol. 2020;34: 2058738420909041.

46. Cheung N, Mitchell P, Wong TY. Diabetic retinopathy. Lancet. 2010;376(9735):124-36

47. Biswas S, Thomas A, Chen S, Aref-Eshghi E, Feng B, Gonder J, Sadikovic B, Chakrabarti S. MALAT1: an epigenetic regulator of inflammation in diabetic retinopathy. Sci Rep. 2018;8(1):6526.

48. Forrester J, Kuffova L, Delibegovic M. The role of inflammation in diabetic retinopathy. Front Immunol. 2020;11:583687.

49. Rangasamy S, McGuire P, Franco Nitta C, Monickaraj F, Oruganti S, Das A. Chemokine mediated monocyte trafficking into the retina: role of inflammation in alteration of the blood-retinal barrier in diabetic retinopathy. PloS ONE. 2014;9(10): e108508.

\section{Publisher's Note}

Springer Nature remains neutral with regard to jurisdictional claims in published maps and institutional affiliations.

Ready to submit your research? Choose BMC and benefit from:

- fast, convenient online submission

- thorough peer review by experienced researchers in your field

- rapid publication on acceptance

- support for research data, including large and complex data types

- gold Open Access which fosters wider collaboration and increased citations

- maximum visibility for your research: over $100 \mathrm{M}$ website views per year

At BMC, research is always in progress.

Learn more biomedcentral.com/submissions 